\title{
Artikel
}

\section{Waardering en de legitieme portie: de consequenties van de verschuiving van een goederenrechtelijke aanspraak naar een verbintenisrechtelijke aanspraak}

\author{
Prof. mr. T.J. Mellema-Kranenburg*
}

\section{Inleiding en probleemstelling}

In het nieuwe erfrecht zoals dat sinds 2003 van kracht is, heeft de legitimaris nog slechts een verbintenisrechtelijke aanspraak op de erfgenamen en - subsidiair - de begiftigden ten bedrage van de helft van de waarde waarover de legitieme wordt berekend gedeeld door het aantal versterferfgenamen (art. 4:64 lid $1 \mathrm{BW}$ ). In artikel 4:65 BW wordt bepaald dat de legitieme porties worden berekend over de waarde van de goederen der nalatenschap, vermeerderd met de in aanmerking te nemen giften en verminderd met de schulden der nalatenschap vermeld in artikel 4:7 sub a tot en met c en f BW. Alle drie deze elementen leveren problemen op in de praktijk. Allereerst is er de vraag van welke waarde uitgegaan moet worden ter berekening van de legitieme. Bij het beoordelen of er sprake is van een gift vormt de bewijslast een groot probleem. En met betrekking tot de aftrekbare schulden rijst de vraag wat onder vereffeningskosten valt en wat niet. Met name de grens tussen boedelkosten, executeurskosten en vereffeningskosten is veelal moeilijk te trekken.

In het onderstaande wil ik mij concentreren op de vraag volgens welke maatstaf de waarde van de goederen der

Prof. mr. T.J. Mellema-Kranenburg is notaris bij Verhees Notarissen in Katwijk en hoogleraar familievermogensrecht aan de Universiteit Leiden. nalatenschap dient te worden vastgesteld en met name wat de invloed van het rechtskarakter van de legitieme (een verbintenisrechtelijke aanspraak) daarop is.

Eerder schreef ik hierover in het WPNR. ${ }^{1}$ Sindsdien zijn er echter een aantal uitspraken gedaan ${ }^{2}$ die enige tekening in de problematiek brengen.

\section{Het juridisch kader}

In artikel 4:65 BW wordt bepaald dat de legitieme wordt berekend over de waarde van de goederen der nalatenschap, vermeerderd met de in aanmerking te nemen giften en verminderd met de schulden der nalatenschap. Onder waarde van de goederen der nalatenschap wordt verstaan de waarde van de goederen onmiddellijk na het overlijden van de erflater (art. 4:6 BW). De legitimaris is, tenzij het testament dat bepaalt, ${ }^{3}$ geen erfgenaam van de erflater, ook niet wanneer hij zich op zijn legitieme portie beroept. Hij heeft slechts een vordering op de erfgenamen. Voor de vaststelling van de waarde van die vordering moet een peildatum bepaald worden. De wet heeft die peildatum, zoals vermeld, gesteld op de datum

1. De invloed van de recessie op de legitieme portie, WPNR (2012) 6956 2. Zie bijvoorbeeld Gerechtshof Den Haag 7 april 2015, ECLI:NL:GHDHA: 2015:1995 en Gerechtshof Arnhem-Leeuwarden 8 december 2015, ECLI:NL:GHARL:2015:9251.

3. Denk aan het geval dat de legitimaris tot erfgenaam benoemd wordt ten bedrage van zijn legitieme portie. 
van overlijden (art. 4:6 BW). ${ }^{4}$ Dat lijkt op zichzelf niet onredelijk. De legitimaris is als hij geen erfgenaam is ook helemaal niet betrokken bij de tegeldemaking van de bestanddelen van de nalatenschap en waarom zou hij dan in het risico, het economisch belang, van deze bestanddelen dat zich realiseert na het moment van vaststellen van zijn aanspraak, meedelen?

In het geval tot een nalatenschap boedelbestanddelen behoren die voor verdeling gereed zijn, bijvoorbeeld een bankrekening, lijkt daar niets tegen. Anders wordt het als die bestanddelen bestaan uit incourante vermogensbestanddelen, zoals moeilijk verkoopbare huizen of sterk in waarde wisselende effecten. Voorts zullen in beide gevallen alvorens de vermogensbestanddelen liquide gemaakt kunnen worden, kosten gemaakt worden. In deze gevallen komt het economisch risico geheel en al bij de erfgenamen te rusten en niet bij de legitimaris. Waarom moet daarbij de positie van de legitimaris anders bezien worden dan die van de erfgenaam? Ik vind dat bijzonder, zelfs ongewenst.

Onder het voor 2003 geldende recht werden de erfgenamen en legitimarissen in gelijke mate getroffen in waardestijging of waardedaling van tot de nalatenschap behorende goederen. Door een beroep op zijn legitieme portie te doen werd een legitimaris erfgenaam en dus ook deelgenoot in de nalatenschap (goederenrechtelijk). Artikel 3:166 lid 3 BW (redelijkheid en billijkheid) was direct op de verhouding tussen erfgenaam en legitimaris van toepassing.

Naar huidig recht heeft de legitimaris die zich op zijn legitieme beroept een (nominale) vordering die in beginsel opeisbaar is zes maanden na overlijden (art. 4:81 $\mathrm{BW})$. De zesmaandentermijn is gekozen om de erfgenamen in de gelegenheid te stellen de legitieme portie liquide te maken, hetgeen bij veel vermogensbestanddelen (huizen, ondernemingen) te kort is. Alleen ingeval er een langstlevende in het spel is, kan de opeisbaarheid worden uitgesteld (wettelijke verdeling of art. 4:82 BW). Bij testament kan de zesmaandentermijn wel worden verlengd, maar dit leidt tot een inferieure making (art. 4:72 en 73 BW) en heeft derhalve geen effect.

De positie van de legitimaris is dus losgekoppeld van die van erfgenaam. Het is op deze manier zeer wel mogelijk dat zowel in relatieve als in absolute zin de legitimaris meer uit de nalatenschap verkrijgt dan de erfgenaam, bijvoorbeeld ingeval er een huis met doorlopende hypothecaire geldlening ${ }^{5}$ is of een (niet aan de erfgenamen te wijten) plotselinge beursval.

Het bovenstaande vind ik niet redelijk. Maar de oplossing hiervoor hoeven we wellicht niet ver te zoeken. De legitimaris is schuldeiser. Hij staat vanaf het moment dat hij aanspraak maakt op zijn legitieme portie tegenover de erfgenaam in de relatie schuldeiser-schuldenaar.

4. Zie M.J.A. van Mourik e.a. (red.), Handboek Erfrecht, Deventer: Kluwer 2015, p. 34 waar wordt geconstateerd dat met deze bepaling enigerlei maatstaf niet is aangereikt.

5. Zie mijn artikel in WPNR (2012) 6956: De invloed van de recessie op de legitieme portie.
Op die verhouding is artikel 6:2 BW van toepassing. ${ }^{6} \mathrm{De}$ redelijkheid en billijkheid brengen mijns inziens mee dat hoewel de onterfde erfgenaam weliswaar niet meer in natura participeert in de boedel en geen deelgenoot is (geen erfgenaam, geen goederenrechtelijke aanspraak), hij wel economisch het lot van de erfgenamen deelt. ${ }^{7}$ De eisen van de redelijkheid en billijkheid bepalen dat de positie van de legitimaris niet losgekoppeld kan worden van die van de erfgenaam; zie wat dat betreft ook de vaststelling van het breukdeel van de legitieme: een van het erfdeel afgeleide aanspraak (art. 4:64 BW).

Ik ben het geheel eens met Heuff wanneer hij stelt dat wanneer de redelijkheid en billijkheid niet de relatie tussen erfgenaam en de legitimaris zou beheersen, het een verstoring van de verhoudingen met zich mee zou brengen en tot moeilijk oplosbare problemen zou kunnen leiden. De conclusie van Heuff is dan ook dat er voor de berekening van de legitimaire massa op dit punt geen verandering zal optreden tussen het vóór en na 2003 geldende erfrecht. De verdelingswaarde voor het erfdeel van de erfgenaam en de waarde van de vordering van de legitimaris dienen hetzelfde lot beschoren te blijven. Dat geldt zowel voor waardedalingen als waardestijgingen.

Tot zover de theorie waar ik nog steeds achter sta. De materie blijft echter in beweging met name in een economie waar vermogensbestanddelen in waarde fluctueren.

\section{De jurisprudentie}

Recent zijn in de jurisprudentie een aantal uitspraken gedaan over de waardering in het kader van de legitieme portie. Ik zal er twee bespreken.

\section{Gerechtshof Den Haag 7 april 2015, ECLI:NL:GHDHA} :2015:1995

In deze casus zijn er een appellante, de enig erfgename, en geïtimeerden, een aantal legitimarissen. In hoger beroep gaat het om de bepaling van de bij de berekening van de legitimaire massa voor de legitieme porties in aanmerking te nemen waarde van de tot de nalatenschap van erflaatster behorende woning. Appellante meent dat uitgegaan moet worden van de verkoopopbrengst, zijnde $€ 168.000$, geïntimeerden van de WOZ-waarde, zijnde $€$ 204.000. Appellante stelt dat de rechtbank weliswaar uitgaat van een soort akkoord tussen partijen omtrent de in aanmerking te nemen waarde in het economisch verkeer, namelijk $€ 168.000$, maar dat deze wilsovereenstemming destijds feitelijk niet mogelijk was vanwege de toekomstige onzekere waardeontwikkeling van de woning en het onzekere tijdstip van verkoop. Geïntimeerden stellen daar tegenover dat er wel degelijk sprake was van overeenstemming omtrent de wijze van waardering van de woning.

Het hof oordeelt dan als volgt:

6. Zie W. Heuff, Afrekenen in het erfrecht vanuit een ander perspectief, in: Yin-Yang (Van Mourikbundel), Deventer: Kluwer 2000, p. 46.

7. Heuff 2000, p. 46. 
'Op grond van art. 4:6 BW moet onder de waarde van de goederen der nalatenschap worden verstaan de waarde op het tijdstip onmiddellijk na het overlijden van erflaatster. Voormeld artikel geeft geen maatstaf voor de waardering, maar in beginsel moet worden uitgegaan van de waarde in het economisch verkeer ten tijde van het overlijden van erflaatster, tenzij er naar redelijkheid en billijkheid in de rechtsverhouding van de erfgename en de legitimarissen uitgegaan moet worden van een andere waarde.'

Dat lijkt dus de goede kant op te gaan, maar helaas gaat het hof niet verder:

'Aan die vraag of in het onderhavige geval daarvan sprake is, komt het hof niet toe. Het hof is van oordeel dat uit de door geïntimeerde overgelegde correspondentie en de toelichting daarop blijkt dat tussen partijen overeenstemming is bereikt over een in het kader van de vaststelling van de legitimaire massa te hanteren waarde van de woning van erflaatster van $€ 204.000,-\cdot$

Maar toch nog een toetje:

'Het hof overweegt voorts dat het in strijd met de tussen de erfgenamen en legitimarissen in ach te nemen beginselen van redelijkheid en billijkheid kan zijn uit te gaan van de waarde van een goed onmiddellijk na het overlijden van erflater. Een zodanige inbreuk op de dwingendrechtelijke regeling van de legitieme portie is echter alleen onder zeer bijzondere omstandigheden gerechtvaardigd. Nu partijen echter terzake de woning een waarde onmiddellijk na het overlijden van erflaatster zijn overeengekomen, komt het hof niet toe aan de vraag of de door appellante aangevoerde omstandigheden in dit geval als zodanig kunnen worden aangemerkt.'

En vervolgens:

Gerechtshof Arnhem-Leeumarden 8 december 2015, ECLI:NL:GHARL:2015:9251

In casu stelt de erfgenaam, de geintimeerde, dat de legitieme aanspraak van appellant verlaagd moet worden met $€ 40.000$, dat is de waardevermindering van de woning die tot de nalatenschap van de moeder behoort sedert haar overlijden. Geïntimeerde c.s. voert daartoe het volgende aan. Het gaat hier in feite om de afwikkeling van twee nalatenschappen, die van de vader en die van de moeder. Appellant is erfgenaam in de nalatenschap van de vader en legitimaris in die van de moeder. Appellant heeft rauwelijks beslag gelegd op alle bestanddelen van de nalatenschap, waaronder de woning, zonder de inhoud van het testament van de moeder te kennen. Vanaf dat moment zijn partijen in langdurige procedures verwikkeld. De kosten zijn opgelopen, zoals daar zijn de kosten van onderhoud van de woning, van gas, water en licht en de woning is ook nog door tijdsverloop in waarde afgenomen. Appellant profiteert van een hogere waarde van de woning die door het beslag onverkoopbaar werd, deelt niet mee in de onderhoudskosten en krijgt ook nog wettelijke rente over de vordering waarvan hijzelf de uitbetaling verhindert. Redelijkheid en billijkheid nopen in deze omstandigheden, aldus geintimeerde, tot een afwijking van de regel in artikel 4:65 en 4:6 BW, en moeten in het kader van de berekening van de legitieme portie leiden tot een verlaging van de waarde van de woning met $€ 40.000$. Appellant stelt daarentegen dat waardevermindering of -vermeerdering na de peildatum van artikel 4:65 jo. 4:6 BW niet relevant is.

Het hof oordeelt:

'Op de verhouding tussen de legitimaris als schuldeiser en de erfgenamen als schuldenaren is art. 6:2 $\mathrm{BW}$ van toepassing. Op grond van deze bepaling zijn [appellant] enerzijds en [geïntimeerde 1] c.s. anderzijds verplicht zich jegens elkaar te gedragen overeenkomstig de eisen van redelijkheid en billijkheid en is een tussen hen krachtens de wet, gewoonte of rechtshandeling geldende regel niet van toepassing, voor zover dit in de gegeven omstandigheden naar maatstaven van redelijkheid en billijkheid onaanvaardbaar is. Artikel 3:12 BW bepaalt dat bij de vaststelling van wat redelijkheid en billijkheid eisen rekening gehouden moet worden met algemeen erkende rechtsbeginselen, met de in Nederland levende rechtsovertuigingen en met de maatschappelijke en persoonlijke belangen die bij het gegeven geval zijn betrokken. [geintimeerde 1] c.s. heeft deze wettelijk verankerde gezichtspunten niet kenbaar betrokken bij zijn stellingen over de door hem gewenste werking van redelijkheid en billijkheid.

(...)

Het hof is van oordeel dat de door [geïntimeerde 1] c.s. aangevoerde feiten en omstandigheden in dit geval niet rechtvaardigen dat de aanvullende of beperkende werking van de redelijkheid en billijkheid ertoe leiden dat de waarde van de woning voor de berekening van de legitieme portie in afwijking van de artikelen 4:65 en 4:6 BW wordt verminderd met $€ 40.000,-$. Het hof overweegt daartoe als volgt. Veel van de omstandigheden die [geintimeerde 1] c.s. aanvoert zijn nu juist inherent aan de wettelijke regeling van de legitieme portie. Dat de waarde daalt of stijgt en dat de kosten na de sterfdatum doorlopen gaat de legitimaris als schuldeiser van de nalatenschap niet aan. Verder staat het [appellant] als schuldeiser van de nalatenschap in beginsel vrij beslag te leggen op de goederen van de nalatenschap. Ten slotte staat ook niet vast dat [geïntimeerde 1] c.s. ten aanzien van de woning een blijvende schade heeft geleden van $€ 40.000,-$. Niet staat vast dat de woning bij verkoop, indien [geintimeerde1] c.s. daartoe al overgaat, minder zal opbrengen dan de waarde van $€ 365.000$,Het moge zo zijn dat door de veelheid van geschillen tussen partijen beider persoonlijke belangen zijn geschaad, maar daarbij staat nog niet vast dat slechts [appellant] daarvan een verwijt kan worden gemaakt.' 
Ook hier dus geen positieve beslissing voor de erfgenaam of toch? Zowel in de uitspraak van Hof Den Haag als in de uitspraak van Hof Arnhem-Leeuwarden wordt de invloed van de redelijkheid en billijkheid op het vraagstuk van de waardering en peildatum in beginsel erkend. Bij de uitspraak van het Hof Den Haag kon het hof niet inhoudelijk ingaan op een toets aan de redelijkheid en billijkheid daar partijen over de waarde reeds een overeenkomst hadden gesloten. Het beginsel werd echter wel erkend. In de uitspraak van het Hof ArnhemLeeuwarden wordt ook uitgegaan van de redelijkheid en billijkheid die de verhouding tussen de erfgenamen en legitimaris beheerst. Ik krijg daarbij de indruk dat aan beide zijden tijdens de procedure en wat daaraan voorafgegaan is, de redelijkheid en billijkheid ver waren te zoeken.

\section{Conclusie}

Per 1 januari 2003 is de legitieme portie wezenlijk van karakter veranderd. $\mathrm{Zij}$ bestaat net als een legaat uit een vorderingsrecht op de erfgenamen. De peildatum voor de waardering van de goederen die tot de legitimaire massa behoren, is in beginsel de waarde onmiddellijk na het overlijden (art. 4:65 jo. 4:6 BW). Sterke waardefluctuaties van de boedelbestanddelen kunnen ertoe leiden dat de legitimaris in vergelijking tot de erfgenaam relatief veel of juist weinig krijgt. Dat is mijns inziens nooit de bedoeling van de wetgever geweest. De legitimaris heeft een van de erfgenaam afgeleid recht; tussen de verkrijging van de legitimaris en de erfgenaam moet een zekere verhouding zitten. Binnen de grenzen van de wet $^{8}$ is dat mogelijk door toepassing van artikel 6:2 BW. De legitieme is weliswaar van dwingend recht, maar wel een verbintenisrechtelijke aanspraak (dus een veel zwakkere aanspraak dan de vroegere goederenrechtelijke aanspraak). Bovendien is nog altijd een van de ratio's van de legitieme: zo veel mogelijk gelijke behandeling van de kinderen ${ }^{9}$ en daarbij past mijns inziens ook een gelijke waarderingsmaatstaf van de tot de nalatenschap behorende goederen. Dus: in beginsel kan het in strijd zijn met de redelijkheid en billijkheid de boedelbestanddelen te waarderen naar de datum van overlijden, maar of dat ook het geval is, zal aan de hand van de omstandigheden (de feiten) getoetst moeten worden. 